\title{
A VERDADE DE MINHAS MENTIRAS
}

\author{
Dizer que o mundo está "diante de nós” significa dizer que não é criação nossa, \\ que a maior parte das coisas no espaço e no tempo são efeitos de causas \\ que não são estados mentais do homem; a "verdade" porém não está "diante de nós": \\ ela só existe onde há linguagens, criações do homem. \\ [de uma página surrupiada do caderno de classe de Fernando Urbi] \\ “- A escribir de otra suerte - dijo Don Quijote -, \\ no fuera escribir verdades, sino mentiras (...)" \\ [Miguel de Cervantes, Don Quijote de la Mancha, segunda parte, cap. III, p 572]
}

Sei de muito poucas coisas, mas me lembro de algumas. Uma das lições mais patéticas que me lembro ter recebido foi sobre a mentira. Quando criança, convivi com um menino que dizia coisas absurdas, das quais só comecei a desconfiar quando o acúmulo de mentiras dele superou o dilatado campo da minha ingenuidade. Até então, para mim, o que ele dizia era tão verdadeiro e real quanto o meu próprio assombro diante dos castelos de realizações e projetos que ele fazia desfilar sobre si mesmo.

Enquanto as outras crianças queriam ser bombeiros, policiais e pilotos de avião, esse menino, cujo nome era Fernando Urbi, dizia estudar muito para ser excelente criminoso. E era surpreendentemente convincente, pois era sério e quase sempre tinha uma informação que calava os outros. Pronunciava, por exemplo, com desenvoltura supostamente a rigor, segundo ele, nomes como Mortimer, Raskolnikov, Jean Valjean. E isso enquanto nós estávamos enrolados com os nomes de jogadores brasileiros de futebol em figurinhas de álbum de banca de jornal.

O limite para mim surgiu numa aula de ciências, na qual, sob sabatina, ele disparou essa: "a senhora sabia que é muito fácil preparar uma bomba de fumaça, normalmente usada em fugas de roubos a banco, e são necessários somente nitrato de potássio, açúcar, bicarbonado de sódio e coloral?" Cansei da minha miséria diante do que ele dizia e revidei considerando tudo mentira, tudo invenção de uma mente doente.

Mas por que mentia? A vida era insuficiente? Sofria em casa com as exigências da família? Sofria de alguma doença misteriosa? O que quer que fosse representava para mim uma manifestação do mal, cuja mentira era a cortina de fumaça a nos envolver e seduzir. E, por contraste, eu nisso me sentia superior a ele, afinal era "normal".

Isso, no entanto, não acabou assim, pois fiquei, durante anos, como que acometido por essa condição, ora de me lembrar reduzido, ora com uma sensação de ter sido excessivo. Não percebia, mas toda a minha atenção estava imantada por essa busca de sentido. É provável, inclusive, que minhas escolhas fossem mais tributárias disso do que eu teria podido reconhecer ou desejar. Muito tempo mais tarde, caiu-me sob os olhos o Dom Quixote. A certa altura do livro, voltoume impressão semelhante a que experimentei diante daquele menino. Foi quando percebi que 
a invenção de Dom Quixote constituía, na verdade, um mundo completamente real para ele. E não importava a comparação com um pretenso real prioritariamente mais verdadeiro ou sequer melhor. Enquanto ao leitor, pasmo e compadecido - eu mesmo, aliás -, atracado com seu sistemazinho de enunciados acanhados, restava lamentar a ilusão do que dizia ver o personagem, para ele transbordava uma circunstância de aventura, de desafios e de conquistas. Matutei indignado: que "sanidade" restritiva era essa na qual fora adestrado a comungar e a defender como critério último?

Foi forte o impacto dessa ideia sobre mim, a ponto de mudar o que pensava sobre Fernando Urbi. Eu que não hesitava em recusar o que ele dizia, fugia da sua presença, tapava os ouvidos quando em aula ele se manifestava, agora vislumbrava um novo significado para tudo aquilo.

Por essa senda empenhei-me, movido por um comportamento que julgava ser semelhante ao do próprio Fernando, em investigar esse nó górdio incrustado no meu pensamento. Ora essa, então não havia mentiras ou verdades? O que existe são acordos tácitos pelos quais os enunciados propostos são avaliados e, nisso, aceitos ou recusados. No primeiro caso, serão chancelados como pertencentes ao celebrado conjunto dos enunciados chamados (com prazo de validade determinado) verdadeiros. Se recusados, parte voltará ao fim da fila dos enunciados candidatos à verificação, parte será ajustada pelos critérios do acordo em voga. O que fez a ruína de Fernando nos acordos do nosso grupo faria seu sucesso em um grupo cujos acordos fossem mais próximos do vocabulário dele. Para nós foi um mentiroso, mas em outra circunstância, talvez em outro tempo, teria sido um visionário. $\mathrm{O}$ terror de perder o chão de uma linguagem segura (eis as grades do calabouço de um outro acordo), nos dava ganas de recusar violentamente as novas imagens propostas por Fernando. Aquilo desfazia nosso sentimento de pertencer a uma única família, o que equivalia a dizer que mexia com nossos brios, daí a negação ostensiva que fazíamos pesar sobre ele. A natureza do seu único "crime", revejo, foi ter recusado a univocidade reinante.

Algum tempo depois dessa espécie de reconversão, tive a impressão de reconhecê-lo na rua. Estava composto, sóbrio e levava um livro sob o braço. Pensei em abordá-lo, mas não tive coragem de enfrentar as injustiças que cometi contra ele. Não tive coragem de reconhecer que, ao falar sobre criminosos literários, sobre nomes complicados em idioma estrangeiro, sobre sua admiração particular pelo ardil dos marginais, ele tinha constituído um mundo paralelo e, agora entendo, muito melhor do que a exígua dieta inventada em nome de um suposto cotidiano ao qual nos submetíamos. Não tive coragem de admitir publicamente a criativa liberdade das suas invenções. Tive, como sempre, um medo ancestral de uma outra verdade possível.

E, no entanto, essa narrativa nada mais foi do que um outro arranjo de enunciados a constituírem uma nova imagem no meu pensamento. Por isso mais verdadeiros?

Denilson Cordeiro é paulistano da zona leste, palmeirense bissexto, ex-jogador de futebol, ex-feirante, ex-balconista, ex-bancário e, nas horas vagas, professor na Unifesp. Publicou a prosa "Oferta" na Ciência e Cultura Vol.61, no.1, 2009. 